Keywords:

Biomass and carbon stocks

Soil layers

Geostatistical analysis

Spatial dependence

Histórico:

Recebido 06/10/2016

Aceito 20/12/2016

Palavras chave:

Estoques de biomassa e carbono

Camadas do solo

Análise geoestatística

Dependência espacial

Correspondência: karlalessandra_afl@hotmail.com

DOI:
Vinícius Augusto Morais', Carla Alessandra Santos', José Márcio Mello², Hassan Camil Dadid3, Emanuel José Gomes Araújo4, José Roberto Soares Scolforo²

\section{SPATIAL AND VERTICAL DISTRIBUTION OF LITTER AND BELOWGROUND CARBON IN A BRAZILIAN CERRADO VEGETATION}

ABSTRACT: Forest ecosystems contribute significantly to store greenhouse gases. This paper aimed to investigate the spatial and vertical distribution of litter, roots, and soil carbon. We obtained biomass and carbon of compartments (litter, roots, and soil) in a vegetation from Cerrado biome, state of Minas Gerais, Brazil. The materials were collected in $70.5 \mathrm{~m}^{2}$ sub-plots randomly allocated in the vegetation. Root and soil samples were taken from five soil layers across the $0-100 \mathrm{~cm}$ depth. Roots were classified into three diameter classes: fine $(<5 \mathrm{~mm})$, medium $(5-10 \mathrm{~mm})$, and coarse $(>10 \mathrm{~mm})$ roots. The carbon stock was mapped through geostatistical analysis. The results indicated averages of soil carbon stock of $208.5 \mathrm{Mg} \cdot \mathrm{ha}^{-1}$ ( $94.6 \%$ of the total carbon), root carbon of 6.8 $\mathrm{Mg} \cdot \mathrm{ha}^{-1}(3.1 \%)$, and litter of $5 \mathrm{Mg} \cdot \mathrm{ha}^{-1}(2.3 \%)$. The root carbon was majority stored in coarse roots $(83 \%)$, followed by fine $(10 \%)$, and medium roots $(7 \%)$. The largest portion of fine roots concentrated in the $0-10 \mathrm{~cm}$ soil depth, whereas medium and coarse roots were majority in the $10-20 \mathrm{~cm}$ depth. The largest portion of soil $(53 \%)$ and root (85\%) carbon were stored in superficial soil layers (above $40 \mathrm{~cm}$ ). As conclusion, the carbon spatial distribution follows a reasonable trend among the compartments. There is a vertical relation of which the deeper the soil layer, the lower the soil and root carbon stock. Excepting the shallowest layer, coarse roots held the largest portion of carbon across the evaluated soil layers.

\section{DISTRIBUIÇÃO ESPACIAL E VERTICAL DO CARBONO EM SERAPILHEIRA E SUBSOLO EM VEGETAÇÃO DO CERRADO BRASILEIRO}

RESUMO: Ecossistemas florestais contribuem significativamente para estocar gases do efeito estufa. Objetivou-se investigar a distribuição espacial e vertical do carbono em serapilheira, raízes e solo. Foram obtidos biomassa e carbono de compartimentos (serapilheira, raiz e solo) em vegetação do bioma Cerrado, Minas Gerais, Brasil. O material foi coletado em 7 sub-parcelas de $0,5 \mathrm{~m}^{2}$ aleatoriamente alocadas na vegetação. As amostras de raízes e solo foram tiradas de cinco camadas do solo na profundidade de $0-100 \mathrm{~cm}$. Raízes foram classificadas em três classes: raízes finas $(<5 \mathrm{~mm})$, médias $(5-10 \mathrm{~mm})$ e grossas $(>10 \mathrm{~mm})$. Estoques de carbono foram mapeados usando análise geoestatística. Resultados

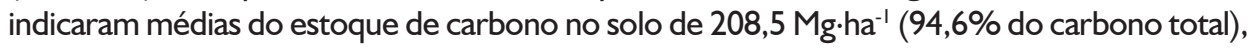

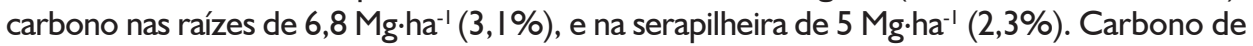
raízes foi majoritariamente estocado nas raízes grossas (83\%), seguido das finas (10\%) e médias (7\%). A maior porção das raízes finas se concentrou na camada de $0-10 \mathrm{~cm}$, enquanto que raízes médias e grossas majoritariamente entre $10-20 \mathrm{~cm}$. A maior porção do carbono em solo (53\%) e raízes (85\%) estiveram estocados nas camadas superficiais do solo (acima de $40 \mathrm{~cm}$ ). Como conclusão, a distribuição espacial do carbono segue razoável tendência entre os compartimentos. Há uma relação vertical de que quanto mais profunda a camada de solo, menor o estoque de carbono de solo e raízes. Com exceção da camada de solo mais superficial, raízes grossas estocaram a maior porção de carbono nas profundidades avaliadas.

\footnotetext{
' University of the State of Mato Grosso - Alta Floresta, Mato Grosso, Brazil

2 Federal University of Lavras - Lavras, Minas Gerais, Brazil

${ }^{3}$ Federal University of Pará - Capitão Poço, Pará, Brazil

${ }^{4}$ Federal Rural University of Rio de Janeiro-Seropédica, Rio de Janeiro, Brazil
} 


\section{INTRODUCTION}

The greenhouse effect is a phenomenon that occurs due to gases concentration in the atmosphere, ensuring the maintenance of temperature in proper levels for survival in the planet (DIAS-FILHO, 2006). Deforestation, forest fires, and fossil fuel burning provoke the intensification of greenhouse gas (GHG) emissions, contributing thus to the global warming.

According to Carvalho et al. (2010), the consequences of global warming are not only of environmental order, but social and economic too. Many researchers have studied globalized strategies to mitigate global warming, in which the need for public policies is seen as essential requirement for reducing GHG emissions, such as carbon dioxide $\left(\mathrm{CO}_{2}\right)$, and methane $\left(\mathrm{CH}_{4}\right)$ (CARVALHO et al., 20I0; TONIOLO and CARNEIRO, 20I0).

Forest ecosystems are the biggest terrestrial carbon sinks in the world, consequently, they play an important role in the global carbon cycle and weather regulation (MARTINS et al., 2003; BARRETO et al., 2009). However, few surveys discuss how carbon cycle behaves in different forest ecosystems.

Carbon stock depends on variables such as local climate, relief, forest species, and soil characteristics, including water and nutrients availability (BROWN and JOHNSTONE, 20II; SCOLFORO et al., 2015), suggesting that carbon is stored differently by ecosystems and biomes.

In 2015, Brazil committed to reduce in $37 \%$ the GHG emissions by 2030 , in relation to the emission from 2005. In this sense, monitoring biomass and carbon stocks has been one of the goals of the National Forest Inventory, being conducted in Brazil. Consequently, carbon content and stock tend to be increasingly more studied in national levels. These analyses involve big-data and costly data processing, requiring reduction of sample size without losing accuracy of estimates.

Specifically in the Brazilian state of Minas Gerais, deforestation and land-use change are the main causes of GHG emission, totalizing $54 \%$ of all emissions in the state (BRASIL, 20I0). Cerrado biome is a savanna vegetation type that shelters more than $50 \%$ of natural vegetation belonging to the state across different physiognomies (OLIVEIRA FILHO and SCOLFORO, 2008). Cerrado Sensu stricto is the most important physiognomy of the state of Minas Gerais, sheltering $28 \%$ of all natural vegetation (CARVALHO et al., 2008). Despite the few studies, Cerrado biome is seen as a relevant site of carbon sink (REZENDE et al., 2006), mainly with respect to soil and root carbon (LIU et al., 20I0).
Surveys indicate that in Cerrado ecosystems, the soil may concentrate more than $70 \%$ of carbon (MORAIS et al., 20I3a; MORAIS et al., 20I3b), however, there is a lack of studies that elucidates how the carbon in soil distributes across the forest and how strong is the dependence between carbon in different compartments, for example soil, roots and litter.

Such analysis depends on tools proper for quantifying carbon stocks in forest ecosystems, thus, researches that approach this subject play a key role in the carbon distribution issue. Studies in this scope help to plan data collection in forest inventories, since they allow stratification into homogeneous areas, which make possible to reduce sample size without losing accuracy.

In this sense geostatistical analysis, such as spatial interpolation technique, has been widely applied in cases involving carbon analysis in large dimension areas (CONSTANTINI et al., 20I2; MISHRA et al., 2012; SCOLFORO et al., 20I5; SCOLFORO et al., 2016). On the other hand, Morais (20l4) detected high heterogeneity of carbon stock in soil, roots and litter in smaller areas, such as vegetation belonging to the Cerrado biome, in the state of Minas Gerais. This induced the author to apply geostatistics in small areas, which enabled him to understand the carbon distribution and existence of correlation between various compartments, then applying the technique in large scale.

Based on this, we conducted this paper assuming the hypothesis that carbon stocks in soil, roots and litter have spatial dependence, allowing the spatialization of these variables by means of ordinary kriging. After quantifying biomass and obtaining carbon content in a vegetation belonging to the Cerrado biome, the aim of this research was to investigate the spatial distribution of litter and the spatial and vertical distribution of belowground carbon, including roots and soil organic matter.

\section{MATERIAL AND METHODS}

\section{Study area and data collection}

The study area was a vegetation belonging to the Cerrado biome, located in Olhos d'Água city, state of Minas Gerais (Figure I).

The studied area is considered as mature vegetation with an area of III.9 ha. This region possesses an annual mean temperature and precipitation of $20.9^{\circ} \mathrm{C}$ and I, I87 $\mathrm{mm}$ respectively, with predominance of latosol.

We used data from $211,000 \mathrm{~m}^{2}$ plots $(10 \times 100$ $\mathrm{m})$ systematically allocated in the vegetation, belonging to the project "Forest Inventory of Minas Gerais". More 


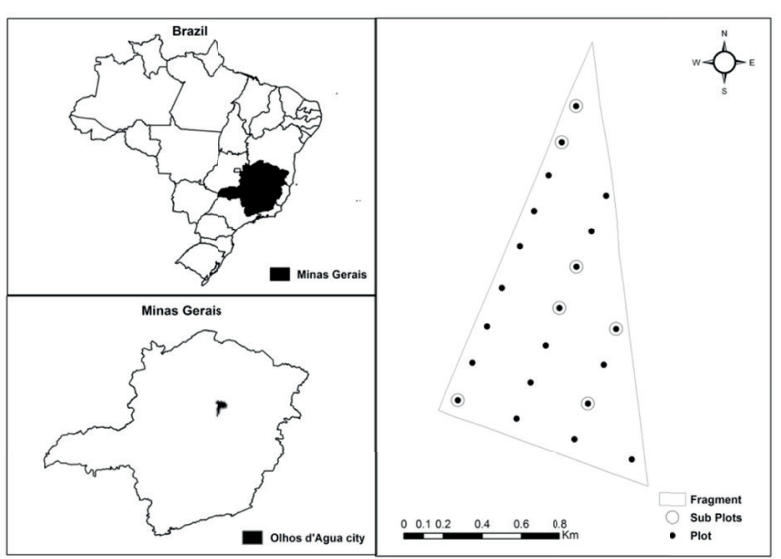

FIGURE I Map illustrating the location of the study area.

information about the project is presented in Scolforo et al. (2008). From these 21 plots, we randomly selected $30 \%$ (7) of them to allocate, also randomly, a $0.5 \mathrm{~m}^{2}(0.5$ x $1.0 \mathrm{~m}$ ) sub-plot in each one. We collected biomass in litter, roots and soil in the seven sub-plots.

All litter over the sub-plot area was gathered, weighted, and put into a bag to take to laboratory for quantification of carbon content and stock. After collecting the litter, we opened a trench of $100 \mathrm{~cm}$ depth on the sub-plots, in order to collect roots and soil. We considered five soil layers: 0 to 10 ; 10 to 20 ; 20 to 40 ; 40 to 60 ; and 60 to $100 \mathrm{~cm}$.

The roots and soil were separated by layer. The roots were classified according to three classes of thickness: $<5 \mathrm{~mm}$ (fine); 5 to $10 \mathrm{~mm}$ (medium); and $>10 \mathrm{~mm}$ (coarse roots). Thicker roots were cut using a pruning saw. More detail about storing, transportation, as well as processing of the collected material can be found in Morais (20l4).

We colected samples from the soil, roots and litter collected in the sub-plots to analyze carbon content and stock on each of these compartments. About 10-12 mg of soil sample and 2-4 mg of litter and root samples were used on the carbon analysis. The equipment Total Organic Carbon (Vario TOC Cube) was used to determinate the carbon content. The samples were packed in tin capsules and burned at $950^{\circ} \mathrm{C}$ for dry combustion.

The emitted carbon dioxide $\left(\mathrm{CO}_{2}\right)$ correspondent to each sample was quantified by an infrared detector NDIR, which relates the $\mathrm{CO}_{2}$ emission with the weight of the samples. These analyses allowed us to compute carbon stock by multiplying biomass obtained in the root and litter samples. The root and litter carbon stock per

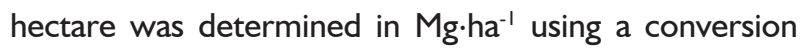
factor of 20,000 , i.e., relation between hectare area $\left(10,000 \mathrm{~m}^{2}\right)$ and sub-plot area $\left(0.5 \mathrm{~m}^{2}\right)$.
To quantify soil carbon stock we pondered the soil density by the depth of each soil layer and its respective carbon content. More details about the procedures to determine carbon stock and sample collection can be found in Morais (20/4).

\section{Geostatistical analysis}

Before performing the geostatistical analysis, we verified the data normality by means of Shapiro-Wilk test at $95 \%$ probability level, whose result confirmed a normal distribution of the dataset.

We developed an experimental semivariogram of the carbon stored in litter, roots and soil (including all layers). In addition, experimental semivariograms also were developed for mean diameter at breast height (dbh) and basal area, in order to verify the existence of similarity on spatial distribution among carbon and stand variables.

Preliminary analysis indicated anisotropy in the semivariograms, allowing us to proceed the modelling and to obtain an isotropic semivariogram, according to Yamamoto and Landin (20I3). Semivariance graphs were generated for the carbon stock in litter, roots, and soil, besides mean diameter and basal area. We also created graphs that show linear trends between carbon stock in the compartments and the stand variables (mean dbh and basal area), aiming to assess their relations.

The Exponential model was fitted using the software GS+ version 10 (ROBERTSON, 1998). This model presents the coefficients nugget $\left(\tau^{2}\right)$, sill $\left(\sigma^{2}\right)$, and range $(\varnothing)$, which were employed in the ordinary kriging.

The Ordinary Least Squares method was applied to fit the models (MELLO et al., 20I2; TERRA, 20I5; SCOLFORO et al., 2016). The method known as ordinary kriging allowed us to estimate carbon stock in litter, roots, and soil for the unsampled areas across the vegetation (JOURNEL and HUIJBREGTS, 1978). Through this step we elaborated carbon stock maps for these three compartments.

\section{RESULTS}

The main descriptive statistics regarding to biomass and carbon stored in litter and roots. We obtained coefficients of variation of biomass and carbon stocks in litter much higher than in roots. The variation of biomass stock was higher than carbon stock, both for litter and root. As expected, the means of biomass and carbon stock were larger in roots than in litter, as well as the carbon content (Table I). 
TABLE I Descriptive statistics of biomass and carbon of litter and root.

\begin{tabular}{|c|c|c|c|c|c|c|}
\hline Compartment & Variables & Mean & Maximum I & Minimum & $\begin{array}{l}\text { Standard } \\
\text { deviation }\end{array}$ & $\begin{array}{c}\text { Coefficient } \\
\text { of Variation } \\
\text { (\%) }\end{array}$ \\
\hline \multirow{3}{*}{ Litter } & $\begin{array}{c}\text { Biomass stock } \\
\left(\mathrm{Mg} \cdot \mathrm{ha}^{-1}\right)\end{array}$ & 11.08 & 23.48 & 4.29 & 6.07 & 54.74 \\
\hline & $\begin{array}{l}C \text { content } \\
(\%)\end{array}$ & 43.94 & 48.01 & 38.5 & 3.34 & 7.61 \\
\hline & $\begin{array}{l}\text { C stock } \\
\left(M^{\prime} \cdot h^{-1}\right)\end{array}$ & 4.97 & 11.27 & 1.91 & 3.06 & 61.61 \\
\hline \multirow{3}{*}{ Root } & $\begin{array}{c}\text { Biomass stock } \\
\qquad\left(\mathrm{Mg} \cdot \mathrm{ha}^{-1}\right)\end{array}$ & 14.34 & 18.27 & 0.24 & 3.43 & 23.88 \\
\hline & $\begin{array}{c}\text { C content } \\
(\%)\end{array}$ & 46.38 & 52.92 & 41.42 & 2.32 & 4.99 \\
\hline & $\begin{array}{l}\text { C stock } \\
\left(M g \cdot h a^{-1}\right)\end{array}$ & 6.76 & 9.61 & 0.11 & 1.73 & 25.62 \\
\hline
\end{tabular}

The distribution of carbon stored in roots across the soil layers, we found great stocking by the coarse roots $(83 \%)$, followed by the fine $(10 \%)$ and medium roots $(7 \%)$. Such percentages totalize a mean amount of $5.6 \mathrm{I}, 0.68$, and $0.47 \mathrm{Mg} \cdot \mathrm{ha}^{-1}$ of carbon stock, respectively. Figure 2 presents bars indicating the percentage of carbon stored in roots and its distribution by soil layer and by root thickness.

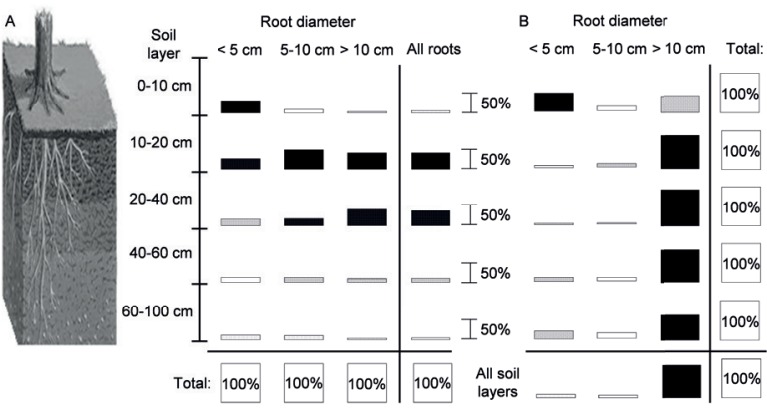

FIGURE 2 Percentage of carbon stored in roots and its distribution by soil layer $(A)$ and by root thickness $(B)$.

The carbon stock from fine roots was more concentrated in the shallowest soil layer, whereas carbon stock from medium and coarse roots was majority concentrated in the 10-20 cm soil layer. Among the five layers, roots within the deeper ones in general contained lower carbon stock than the shallower layers, excepting the $0-10 \mathrm{~cm}$ layer. The $10-20$ and $20-30 \mathrm{~cm}$ layers concentrated the highest carbon levels stored in roots (Figure $2 \mathrm{~A}$ ), totalizing around $80 \%$. Thus, the roots above the $30 \mathrm{~cm}$ depth held more than $85 \%$ of the total root carbon.

Besides the fact that fine roots concentrated more carbon in the first layer, they also stored a larger portion of carbon (40\%) than the thicker roots, in the shallowest layer. However, considering the other soil layers, i.e., the $20-100 \mathrm{~cm}$ depth, the coarse roots hold the largest amount of carbon when compared to the other roots.
The coarse root stocks ranged from 64\% (60$100 \mathrm{~cm})$ up to $93 \%(10-20 \mathrm{~cm}$ layer $)$ of the carbon in all roots. Considering the soil layers as a whole, the coarse roots stored much more carbon (about 84\%) than the other ones, which reached less than $9 \%$ of the total root carbon (Figure 2B). We plotted mean root and soil carbon in function of the layer depth (Figure 3). Figure $3 \mathrm{~B}$ presents the soil carbon stored by layer per $\mathrm{cm}$.

A

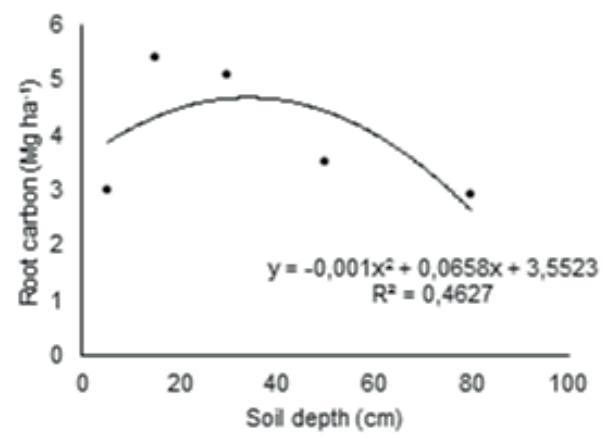

B

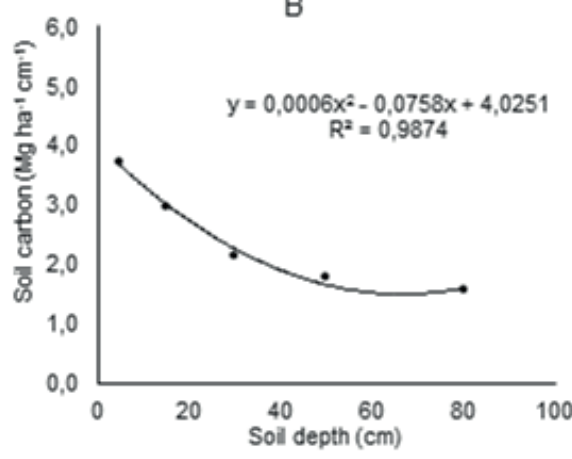

FIGURE 3 Concentration of root (A) and soil (B) carbon in relation to the soil depth.

Figure $3 \mathrm{~A}$ shows a parabolic trend indicating that the larger portion of root carbon is stored across the 10 $40 \mathrm{~cm}$ soil depth. In addition, there is a clear trend in decreasing the stock above and below this layer. The soil carbon stock tended to decrease directly proportional to the soil depth (Figure 3B). Table 2 presents the main descriptive statistics of soil carbon stock and carbon content by soil depth.

Considering all layers, the mean soil stock was 208.5 $\mathrm{Mg} \cdot \mathrm{ha}^{-1}$, corresponding to a mean stock of $4 \mathrm{I} .7$ $\mathrm{Mg} \cdot \mathrm{ha}^{-1} \cdot$ layer $^{-1}$. The coefficients of variations of carbon stock, for all soil layers, were lower than those values seen in Table I. However, the variations of the carbon contents in soil (Table 2) were higher than the values found for litter and roots (Table I).

Contrary to what was found in the roots, the $10-20 \mathrm{~cm}$ layer had the lowest carbon concentration 
TABLE 2 Descriptive statistics of soil carbon content and stock across soil depths.

\begin{tabular}{|c|c|c|c|c|c|c|}
\hline Soil depth & Variables & Mean & Maximum & Minimum & $\begin{array}{l}\text { Standard } \\
\text { deviation }\end{array}$ & $\begin{array}{l}\text { Coefficient of } \\
\text { Variation (\%) }\end{array}$ \\
\hline \multirow{2}{*}{$0-10$} & $\begin{array}{c}\text { C content } \\
(\%)\end{array}$ & 4.47 & 5.36 & 3.20 & 0.68 & 15.33 \\
\hline & 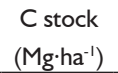 & 37.35 & 45.16 & 24.92 & 6.73 & 18.03 \\
\hline \multirow{2}{*}{$10-20$} & $\begin{array}{c}\text { C content } \\
(\%)\end{array}$ & 3.29 & 4.06 & 2.51 & 0.53 & 16.09 \\
\hline & 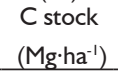 & 29.54 & 35.82 & 23.01 & 4.07 & 13.77 \\
\hline \multirow{2}{*}{$20-40$} & $\begin{array}{c}\text { C content } \\
(\%)\end{array}$ & 2.34 & 3.37 & 1.63 & 0.62 & 26.45 \\
\hline & $\begin{array}{l}\text { C stock } \\
\left(\mathrm{Mg} \cdot \mathrm{ha}^{-1}\right)\end{array}$ & 43.06 & 63.56 & 27.83 & 12.44 & 28.90 \\
\hline \multirow{2}{*}{$40-60$} & $\begin{array}{c}\text { C content } \\
(\%)\end{array}$ & 1.89 & 2.52 & 1.47 & 0.35 & 18.67 \\
\hline & $\begin{array}{l}\text { C stock } \\
\left(\mathrm{Mg} \cdot \mathrm{ha}^{-1}\right)\end{array}$ & 35.80 & 44.85 & 27.91 & 5.57 & 15.56 \\
\hline \multirow{2}{*}{$60-100$} & $\begin{array}{c}\text { C content } \\
(\%)\end{array}$ & 1.55 & 2.26 & 1.18 & 0.39 & 24.90 \\
\hline & $\begin{array}{l}\text { C stock } \\
\left(\mathrm{Mg} \cdot \mathrm{ha}^{-1}\right)\end{array}$ & 62.74 & 88.22 & 43.04 & 15.33 & 24.43 \\
\hline
\end{tabular}

(about $23 \mathrm{Mg} \cdot \mathrm{ha}^{-1}$ ) of carbon in soil, whereas the 60$100 \mathrm{~cm}$ layer stores the largest portion $\left(88.2 \mathrm{Mg} \cdot \mathrm{ha}^{-1}\right)$. However, we emphasize that the $60-100 \mathrm{~cm}$ layer is four times thicker than the $10-20 \mathrm{~cm}$ layer, therefore, such relation inverts when considered the amount of carbon per centimeter (Figure 3B).

We related the variables mean $\mathrm{dbh}$ and basal area of the plots (where sub-plots were allocated), in function of carbon stored in litter, soil, and roots (Figure 4).

The simple linear models and the coefficients of determination $\left(R^{2}\right)$ indicated weak correlations between the tested variables, excepting the situations shown in Figures 4D and 4F. In both cases a relatively strong correlation was detected for the carbon stored in litter and roots, in relation to the mean dbh.
The exponential model was able to describe the behavior of the variogram in all cases. The autocorrelation distance among the samples was equal to 714,342 , and $933 \mathrm{~m}$, respectively for litter, roots, and soil. The degree of spatial dependence, which was used to characterize the intensity of the structure of spatial dependence, was classified as strong for all variables, according to the classification proposed by Cambardella et al. (1994). Through the parameters of the exponential model, we elaborated the ordinary kriging maps with the distribution of carbon stored in litter, soil, and roots (Figure 4).

The three studied compartments store an amount

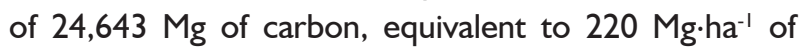
carbon, of which $94.5 \%$ is held in the soil $(0-100 \mathrm{~cm})$, $3.1 \%$ in the roots, and $2.4 \%$ in litter.

\section{DISCUSSION}

The mean litter biomass ( $11.08 \mathrm{Mg} \cdot \mathrm{ha}^{-1}$ ) obtained in this study was almost two times above the values found by Aquino et al. (2016), which was $6.4 \mathrm{Mg} \cdot \mathrm{ha}^{-1}$, and Ribeiro et al. (200I), which was 6.3 Mg.ha- ${ }^{-1}$. Morais (2014) also assessed litter biomass from the Cerrado, however the author collected data from 20 areas, encountering a mean value of $8.7 \mathrm{Mg} \cdot \mathrm{ha}^{-1}$, indicating strong evidence that the vegetation studied in this research possess a wellstocked litter.

We obtained a carbon content of litter close to $44 \%$ (Table I), which is a little above the value of $37 \%$ suggested by the Intergovernmental Panel on Climate Change (IPCC). Morais et al. (2014) obtained a content much closer (43.2\%) for litter.

Regarding to the carbon content of roots, the mean value reached $46.4 \%$, which is within the expected
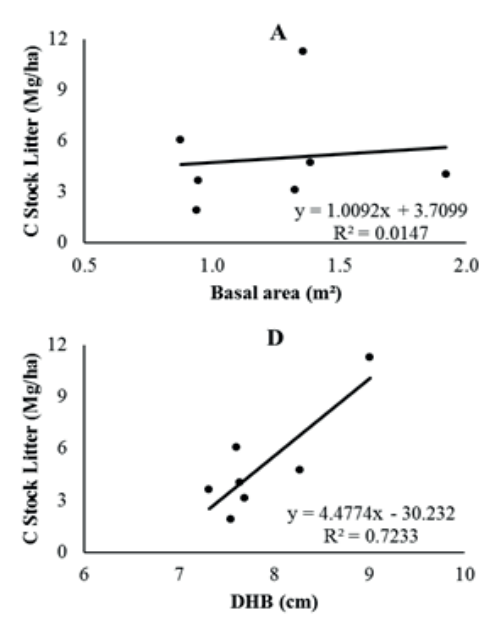
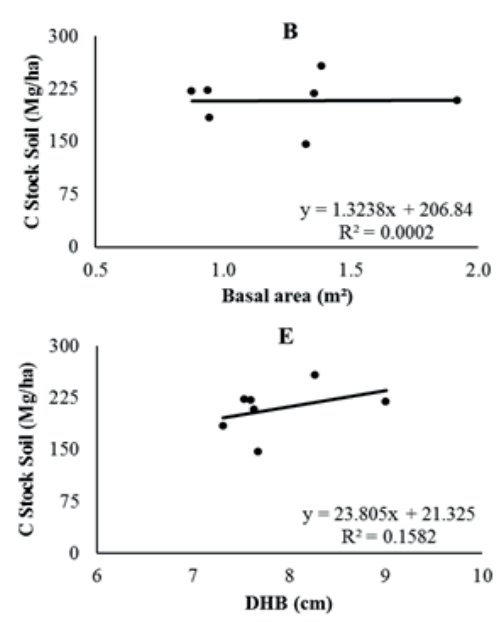

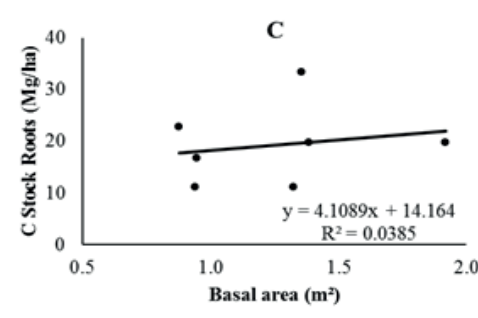

F

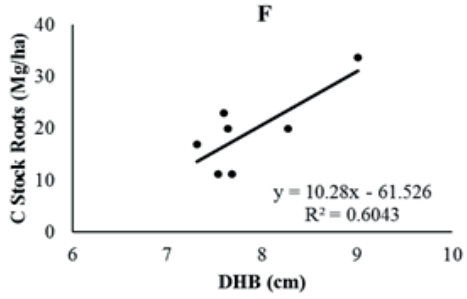

FIGURE 4 Behavior of carbon stored in litter ( $A$ and $D)$, soil ( $B$ and $E)$, and roots ( $C$ and $F)$ in function of mean dbh and basal area. 
range of $40-60 \%$ for vegetal materials as reported by Barbosa et al. (20I2). Such value also corroborates the mean carbon content of roots found by Morais (20I4), in vegetation from Cerrado in the state of Minas Gerais.

As shown in Figure 2B, the coarse roots held the largest portion of the biomass and carbon stored in the roots. According to Barbosa et al. (2012) and Azevedo (2014), this behavior occurs because thicker roots store majority carbon, whereas fine roots are responsible for transporting water and nutrients from the soil to the plant (TUFEKCIOGLU et al., 1999).

Barbosa et al. (2012) describes that fine roots are found mainly in supercial soil layers, what was found in this study such as shown in Figure 2. In addition, we detected that the largest amount (42\%) of roots was contained in the $0-20 \mathrm{~cm}$ soil layer, such as obtained by Castellanos et al. (199I), Barbosa et al. (2012), and Albuquerque et al. (20I5). This root concentration in superficial layers occurs in response of the available nutrients due to organic matter decomposition, which decreases in deeper layers (ALBUQUERQUE et al., 20I5; ARAÚjO et al., 2007; BALIEIRO et al., 2005; BARBOSA et al., 20I2; SAYER et al., 2006; SELLE et al., $2010)$. Root biomass is one of the factors that contributes to the soil carbon stock, however, Costa et al. (20l4) state that biomass in roots is accumulated slower than the aerial biomass, since they may take various decades to stabilize growth. Climate, vegetation, soil type, and soil texture, and interaction among them, is another factor that affects the carbon stored in soil (LAL, 2005, LEIFELD et al., 2005). Such condition makes the soil carbon stock quite variable even in equal vegetation type sites, as can be seen in IPCC (2000), Melo and Durigan (2006), Paiva et al. (20I I), and Morais (20I4).

The soil carbon stock ranged from $23.0 \mathrm{l} \mathrm{Mg} \cdot \mathrm{ha}^{-1}$ ( 10 -

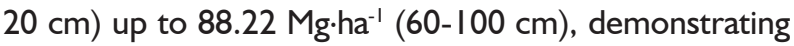

high vertical variability (Table 2 ). However, we highlight that the soil layers possess different depths. As the soil carbon stock was computed per centimeter in Figure $3 \mathrm{~B}$, we obtained a relation indicating that the deeper the layer, the lower the carbon stock, meaning that superficial layers contain the largest carbon stock per centimeter.

The soil carbon content, in turn, followed a decaying trend of its value with the increasing of the soil depth, such as noted by Jobbágy and Jackson (2000), Salton et al. (20I I), Sheikh et al. (2009), and Zinn et al. (20I2).

The kriging maps allowed us to obtain the total amount of carbon stored across the vegetation. As expected, the soil was responsible for the largest total carbon stock $(25,424.9 \mathrm{Mg})$, followed by roots $(2,235 . \mathrm{l} \cdot \mathrm{Mg})$, and litter $(530.8 \mathrm{Mg})$.

The spatial autocorrelations were satisfactory because the spatial dependence was above the minimal distance between samples $(250 \mathrm{~m})$. The ordinary kriging maps of carbon stored in litter (Figure 5A), roots (Figure $5 \mathrm{~B}$ ), and soil (Figure 5C) indicates a carbon gradient in such compartments across the vegetation.

With regards to the carbon spatial distribution across the vegetation, the maps of carbon distribution (Figure 5) are reasonably resembled. The region with larger concentrations (upper class) of carbon stored in litter and soil overlapped, such as larger part of the middle and lower classes. However, some regions occupied by the middle class in the map of soil carbon distribution overlapped regions occupied by the lower class in the litter map.

Likewise, the map of root carbon distribution shows that the upper class is allocated exactly in the region where the lower class is allocated in the maps of litter and soil. However, a considerable portion of the lower and middle classes overlapped in relation to the maps of litter and soil.
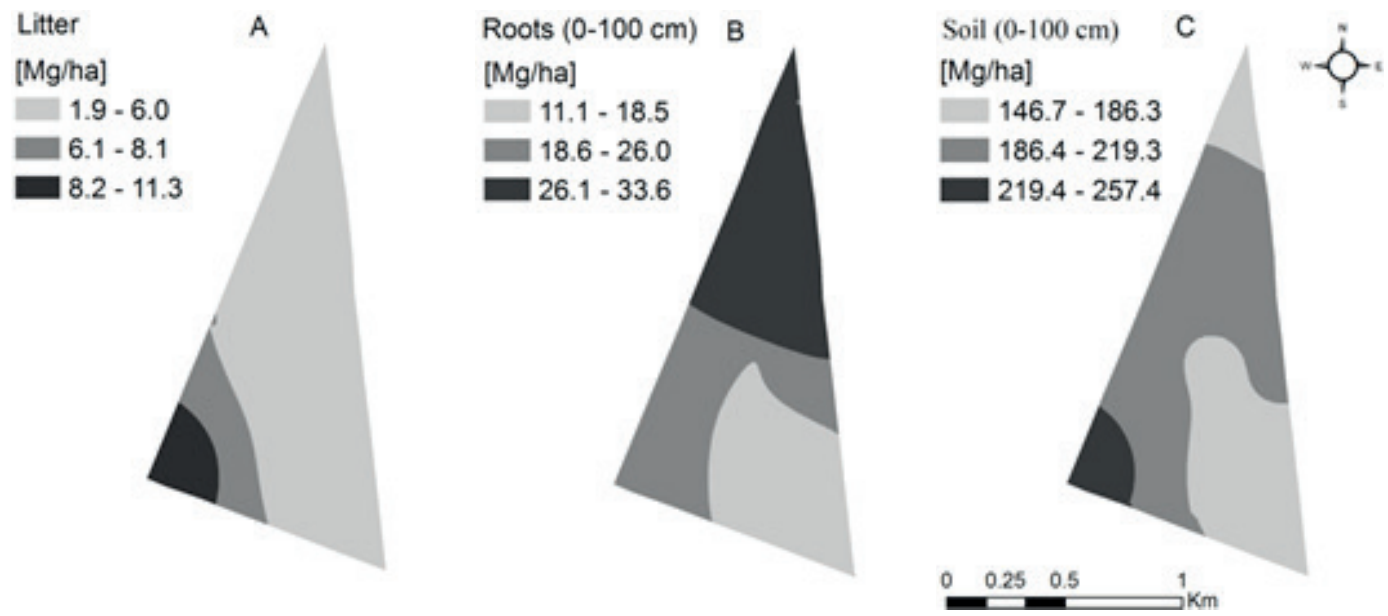

FIGURE 5 Distribution of carbon stored in litter (A), roots (B), and soil (C). 

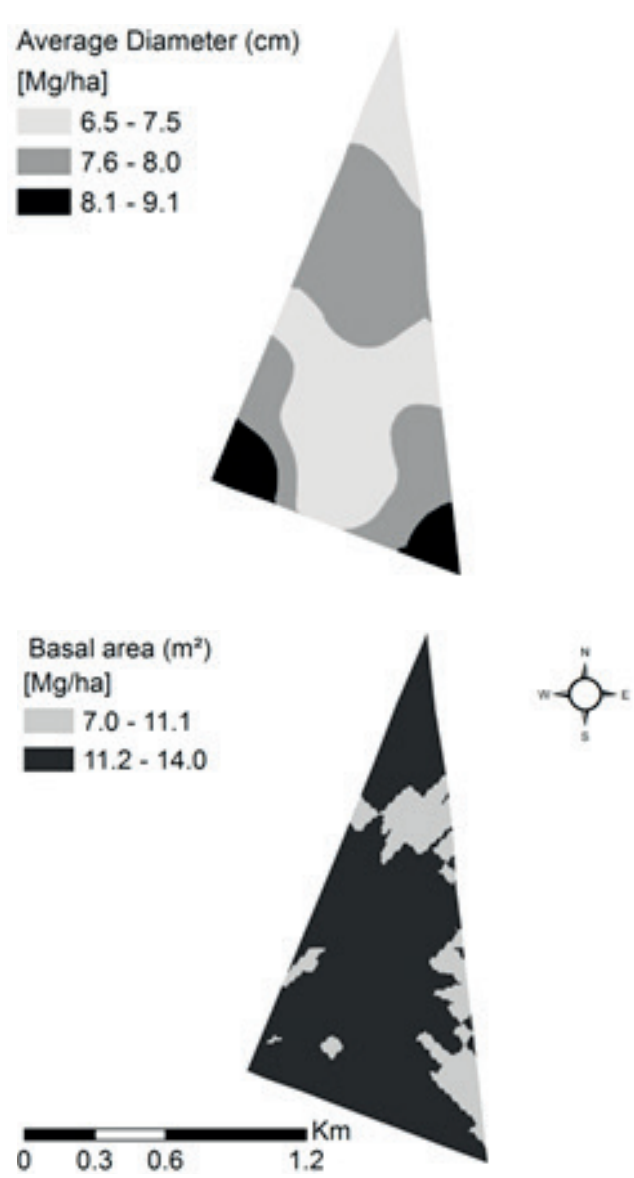

FIGURE 6 Spatial distribution of average diameter and basal area.

Terra et al. (20/5) found spatial correlation between aerial carbon and soil organic matter using cokriging technique. Knowing that the aerial carbon of trees depends on its diameter, it is expected that the carbon in soil increases in the extent the trees grow in diameter. This relation can be associated with the results shown in Figures 4, 5, and 6 . Thus, it was observed that regions with the larger amounts of carbon stored in litter and soil were reasonably in accordance to the ones where we found the larger diameters.

As shown in Figure 4, a relation between carbon and basal area was not detected and this may be associated with the density of plants. Basal area tends to increase as much as the density increases, as consequence, this provokes a reduction of the mean $\mathrm{dbh}$, and therefore the dependence with basal area is lost.

\section{CONCLUSION}

The carbon spatial distribution follows a reasonable trend among litter, roots, and soil, although it is stronger between litter and soil. This moderate similarity means that well- and low-stocked regions may overlap considering the litter, root, and soil carbon distribution.
In regards to the vertical distribution, there is a relation in which the deeper the soil layer, the lower the soil and root carbon stock. Excepting the shallowest soil layer, coarse roots held the largest portion of carbon across the evaluated soil layers.

\section{REFERENCES}

ALBUQUERQUE, E. R.; SAMPAIO, E. V.; PAREYN, F. G.; ARAÚJO, E. L. Root biomass under stem bases and at different distances from trees. Journal of Arid Environments, v. I I6, p. 82-88, 2015.

AMARAL, A. G.; PEREIRA, F. F. O.; MUNHOZ, C. B. R. Fitossociologia de uma área de cerrado rupestre na fazenda Sucupira, Brasília-DF. Cerne, v. I2, n. 4, p. 350$359,2006$.

AQUINO, P. S. R.; NAPPO, M. E.; RODRIGUES, M. S.; PEREIRA, I. M.; MATRICARDI, E. A. T.; PELÁ, G. M. Análise espacial da produtividade de serapilheira em uma mata de galeria. Ciência florestal, v. 26, n. 2, p. 489-500, 2016.

ARAÚJO, E. J. G. de; SOUZA, F. N. de; SCOLFORO, J. R. S.; MELLO, J. M. de; SILVA, C. P. C. Diversidade e estrutura de seis fragmentos de cerrado stricto sensu no extremo norte de Minas Gerais. Revista Brasileira de Biociências, v. 5, p. 546-548, 2007.

AZEVEDO, G. B. Amostragem e modelagem da biomassa de raízes em um cerrado sensu stricto no Distrito Federal. 20I4. 75 p. Dissertação de Mestrado. Universidade de Brasília, Brasília.

BALIEIRO, F. C.; CEDDIA, M. B.; PEREIRA, M. G.; RESENDE, A. S.; FRANCO, A. A. Biomassa de raízes e regime hídrico do solo em plantio de Pseudosamanea guachapele (Kunth) Harms em um planossolo háplico. Floresta, v.35, n. 2, p.22I-230, 2005.

BARBOSA, R. I.; SANTOS, J. R. S.; CUNHA, M. S.; PIMENTEL, T. P.; FEARNSIDE, P. M. Root biomass, root: shoot ratio and belowground carbon stocks in the open cerrados of Roraima, Brazilian Amazonia. Australian Journal of Botany, v. 60, p. 405-4I6, 2012.

BARRETO, L. V; FREITAS, A. C. S.; PAIVA, L. C. Sequestro de carbono. Enciclopédia Biosfera, n.7, p. I-10, 2009.

BRASIL. Ministério da Ciência e Tecnologia. Segundo inventário brasileiro de emissões e remoções antrópicas de gases de efeito estufa: emissões de gases de efeito estufa no setor uso da terra, mudanças do uso da terra. Brasília, 2010.

BROWN, C. D.; JOHNSTONE, J. F. How does increased fire frequency affect carbon loss from fire? A case study in the northern boreal forest. International Journal of Wildland Fire, v. 20, n. 7, p. 829-837, $201 \mathrm{I}$. 
CAMBARDELLA, C. A.; MOORMAN, T. B.; PARKIN, T. B.; KARLEN, D. L.; NOVAK, J. M.; TURCO, R. F.; KONOPKA, A. E. Field-scale variability of soil properties in central lowa soils. Soil science society of America journal, v. 58(5), p. I50I-I5II, 1994.

CARVALHO, L. M. T.; J. R.S.; ACERBI JUNIOR, F. W.; SILVEIRA, E. M. O.; OLIVEIRA, L. T. Análises espaciais e estatísticas da flora nativa em Minas Gerais. In: CARVALHO, L. M. T.; SCOLFORO, J. R. Monitoramento da flora nativa. I. ed. Lavras: UFLA, 2008. p.25-316.

CARVALHO, J.L.N.; RAUCCI G. S.; CERRI, C. E. P.; BERNOUX MARTIAL.; FEIGL B. J.; WRUCK, F. J.; CERRI, C. C. Impact of pasture, agriculture and crop-livestock systems on soil $\mathrm{C}$ stocks in Brazil. Soil Tillage Research, v. I I0, p. I75- I86, 2010.

CASTELLANOS, J.; MAASS, M.; KUMMEROW, J. Root biomass of a dry deciduous tropical forest in Mexico. Plant and Soil, v. |31, n. 2, p. 225-228, I99|.

CONSTANTINI, M.L.; ZACCARELLI, N.; MANDRONE, S.; ROSSI, D.; CALIZZA, E.; ROSSI, L. NDVI spatial pattern and the potential fragility of mixed forested areas in volcanic lake watersheds. Forest Ecology and Management. v. 285, p. I33-|4I, 2012.

COSTA, T. L.; SAMPAIO, E. V. S. B.; SALES, M. F.; ACCIOLY, L. J. O.; ALTHOFF, T. D.; PAREYN, F. G. C.; ALBUQUERQUE, E. R. G. M.; MENEZES, R. S. C. Root and shoot biomasses in the tropical dry forest of semi-arid Northeast Brazil. Plant and soil, 378(I-2), p. I I3-I23, 2014.

DIAS-FILHO, M. B. A fotossíntese e o aquecimento global. Belém, PA: Embrapa Amazônia Oriental, (Embrapa Amazônia Oriental, Documentos, 234), p. 24, 2006.

INTERGOVERNMENTAL PANEL ON CLIMATE CHANGE IPCC. Land use change and forestry. In: Revised 1996 guidelines for national GHG inventories: reference manual. 1996. p. 5.I-5.75.

INTERGOVERNMENTAL PANEL ON CLIMATE CHANGE - IPCC. Land use, land use change and forestry. Cambridge: Cambridge University Press, UK, 2000.

JOBBÁGY, E. G.; JACKSON, R.t B. The vertical distribution of soil organic carbon and its relation to climate and vegetation. Ecological applications, v. 10, n. 2, p. 423436, 2000.

JOURNEL, A. G.; HUIJBREGTS, C. J. Mining geostatistics. London: Academic, p. 600, 1978.

LAL, R. Forest soils and carbon sequestration. Forest Ecology and Management, v. 220, p. 242-258, 2005.

LEIFELD, J.; BASSIN, J.; FUHRER, J. Carbon stocks in Swiss agricultural soils predicted by land-use, soil characteristics, and altitude. Agriculture, Ecosystems \& Environment, v. I05, p. 255-266, 2005.
LINDOSO, G. S. Cerrado sensu stricto sobre neossolo quartzarênico: fitogeografia e conservação. 2008. 186 p. Dissertação (Mestrado em Ecologia) - Universidade de Brasília, Brasília.

LIU, F.; WU, X. B.; BAI, E.; BOUTTON, T. W.; ARCHER, S. R. Spatial scaling of ecosystem $C$ and $N$ in a subtropical savanna landscape. Global Change Biology, v. I6, n. 8, p. 2213-2223, 2010.

MARTINS, C. R.; PEREIRA, P. A. P.; LOPES, W. A.; ANDRADE, J. B Ciclos globais de carbono, nitrogênio e enxofre. Cadernos Temáticos de Química Nova na Escola, n.5, p.28-4I, 2003.

MELO A. C. G.; DURIGAN, G. Fixação de carbono em reflorestamentos de matas ciliares no Vale do Paranapanema, SP, Brazil. Scientia Forestalis, n. 7I, p. |49-| 54, 2006.

MELLO, C.R.; NORTON, L. D.; CURI, N.; YANAGI, S. N. M. Sea surface temperature (SST) and rainfall erosivity in the Upper Grande River Basin, Southeast Brazil. Ciência e Agrotecnologia, v. 36, n. I, p. 53-59, 2012.

Ministério do Meio Ambiente. 2016. Available at: <http:// www.mma.gov.br/clima/convencao-das-nacoes-unidas/ acordo-de-paris > Accessed in: 30 nov 2016.

MISHRA, U.; TORN, M. S.; MASANET, E.; OGLE, S. M. Improving regional soil carbon inventories: Combining the IPCC carbon inventory method with regression kriging. Geoderma, v. 189-190, n. II, p. 288-295, 2012.

MORAIS, V. A.; SCOLFORO, J. R. S.; SILVA, C. A.; MELLO, J. M.; GOMIDE, L. R.; OLIVEIRA, A. D. Carbon and biomass stocks in a fragment of cerradão in Minas Gerais state, Brazil. Cerne, v. 19, n. 2, p. 237-245, 2013a.

MORAIS, V. A.; SILVA, C. A.; SCOLFORO, J. R. S.; MELLO, J. M.; ARAÚJO, E. J. G.; ASSIS, E. A. Modelagem do teor de carbono orgânico de fragmentos de cerrado de Januária e Bonito de Minas, Minas Gerais. Pesquisa Florestal Brasileira, v. 33, n. 76, p. 343-354, 20 I3b.

MORAIS, V. A. Carbono no cerrado de Minas Gerais: modelagem e estoques em solo, raízes e serrapilheira. 2014. II7 p. Tese (doutorado) - Universidade Federal de Lavras, Lavras.

MORAIS, V. A.; MELLLO, J. M. D.; GOMIDE, L. R.; SCOLFORO, J. R. S.; ARAÚJO, E. J. G. D.; RUFINI, A. L. Influence of diameter measuring height on the adjustment of volume and biomass equations of cerrado in Minas Gerais. Ciência e Agrotecnologia, v. 38, p. 230-239, 2014.

OLIVEIRA FILHO, A. T.; SCOLFORO, J. R. S. Inventário florestal de Minas Gerais: espécies arbóreas da flora nativa. Lavras: Editora da UFLA, 2008. 619 p.

PAIVA, A. O.; REZENDE, A. V.; PEREIRA, R. S. Estoque de carbono em cerrado Sensu Stricto do Distrito Federal. Revista Árvore, v. 35, n. 3, p. 527-538, 201 I. 
REZENDE, A. V.; VALE, A. T.; SANQUETTA, C. R.; FIGUEIREDO FILHO, A.; FELFILI, J. M.. Comparison of mathematical models to volume, biomass and carbon stock estimation of the woody vegetation of a Cerrado Sensu Stricto in Brasília, DF. Scientia Forestalis, v. 7I, p. 65-76, 2006.

RIBEIRO JUNIOR P. J.; DIGGLE, P. J. geoR: a package for geostatistical analysis. R-News, v. I, n. 2, p. I4-I8, 200 I.

ROBERTSON, G.P. GS+: Geostatistics for the environmental sciences, Version 5.03 Beta. Gamma Design Software, Plainwell, 1998.

SALTON, J. C.; MIELNICZUK, J.; BAYER, C.; FABRÍCIO, A. C.; Manuel Cláudio Motta MACEDO, M. C. M.; BROCH, D. L. Teor e dinâmica do carbono no solo em sistemas de integração lavoura-pecuária. Pesquisa Agropecuária Brasileira, v. 46, p. I349-1356, 201 I.

SAYER, E. J.; TANNER, E. V. J.; CHEESMAN, A. W. Increased litterfall changes fine root distribution in a moist tropical forest. Plant and Soil, 28I(I-2), p. 5-13, 2006.

SCOLFORO, J. R.; MELLO, J. M.; OLIVEIRA, A. D.; CARVALHO, L. M. T.; ACERBI JUNIOR; F. W. Amostragem e caracterização dos fragmentos inventariados. In: SCOLFORO, J. R.; MELLO, J. M.; OLIVEIRA, A. D. Inventário florestal de Minas Gerais: cerrado: florística, estrutura, diversidade, similaridade, distribuição diamétrica e de altura, volumetria, tendências de crescimento e áreas aptas para manejo florestal. Lavras: UFLA, 2008. p. I-76.

SCOLFORO, H.F.; SCOLFORO, J. R. S.; MELLO, C. R.; MELLO, J. M.; FERRAZ FILHO, A. C. Spatial distribution of aboveground carbon stock of the arboreal vegetation in Brazilian biomes of Savanna, Atlantic Forest and Semi-Arid Woodland. Plos One, v. I0, n. 6, p. I-20, 2015.
SCOLFORO, H. F.; SCOLFORO, J. R. S.; MELLO, J. M.; MELLO, C. R.; MORAIS, V. A. Spatial interpolators for improving the mapping of carbon stock of the arboreal vegetation in Brazilian biomes of Atlantic forest and Savanna. Forest Ecology and Management, v. 376, p. 24-35, 2016.

SELLE, G. L.; Elisabete VUADEN, E.; MURARI, A. B.; HACK, C.; FARIAS, J. A.; THOMA, R. Biomassa radicular, densidade do solo e análise química do solo de um povoamento de Pinus sp. Ambiência, v.6, n. I, p.6I-74, 2010.

SHEIKH, M.; KUMAR, M.; BUSSMANN, R. W. Altitudinal variation in soil organic carbon stock in coniferous subtropical and broadleaf temperate forests in Garhwal Himalaya. Carbon balance and management, v. 4, n. 6, p. I-6, 2009.

TERRA, M. C. N; Mello, J. M.; Mello, C. R. Relação espacial do carbono da vegetação e matéria orgânica do solo na Serra da Mantiqueira. Floram, v. 22, n. 4, p. 446-455, 2015.

TONIOLO J. C.; CARNEIRO C. D. R. Processos geológicos de fixação do carbono na terra e aquecimento global. Terra e Didática, v.6, n.I, p.3I-56, 2010.

TUFEKCIOGLU, A.; RAICH, J. W.; ISENHART, T. M.; SCHULTZ, R. C. Fine root dynamics, coarse root biomass, root distribution, and soil respiration in a multispecies riparian buffer in Central lowa, USA. Agroforestry Systems, v. 44, p. 163-174, 1999.

YAMAMOTO, J. K.; LANDIN, P. M. B. Geoestatística: conceitos e aplicações. São Paulo: Oficina de Textos, 2013.

ZINN, Y. L.; GUERRA, A. R.; SILVA, A. C.; MARQUES, J. J.; OLIVEIRA, G. C. D.; CURI, N. Perfis de carbono orgânico do solo nas regiões Sul e Serra do Espinhaço Meridional, Minas Gerais: modelagem em profundidade. Revista Brasileira de Ciência do Solo, v. 36, p. |395-|406, 2012. 
